\title{
Demeclocycline Hydrochloride
}

National Cancer Institute

\section{Source}

National Cancer Institute. Demeclocycline Hydrochloride. NCI Thesaurus. Code C28975.

The hydrochloride salt of demeclocycline, a broad-spectrum, tetracycline derivative exhibiting antimicrobial, aquaretic and chelating activities. In bacteria, demeclocycline binds reversibly to the 30 S ribosomal subunit and blocks the binding of aminoacyl-tRNA to the A-site of the mRNA-ribosome complex, resulting in the inhibition of protein synthesis and bacterial cell death. In mammals, this agent interferes with the action of antidiuretic hormone (ADH) at the level of the renal collecting tubule, resulting in aquaresis. In addition, demeclocycline, which like other tetracyclines chelates calcium in bone and exhibits a yellow fluorescence under ultraviolet (UV) light, may be used as a fluorescent bone-labeling agent in bone histomorphometry. 